\title{
Chapter 9 \\ Secondary School Mathematics Teacher Education in the Netherlands
}

\author{
Joke Daemen, Ton Konings and Theo van den Bogaart
}

\begin{abstract}
In this chapter, we discuss the education of secondary school mathematics teachers in the Netherlands. There are different routes for qualifying as a secondary school mathematics teacher. These routes target different student teacher populations, ranging from those who have just graduated from high school to those who have already pursued a career outside education or working teachers who want to qualify for teaching in higher grades. After discussing the complex structure this leads to, we focus on the aspects that these different routes have in common. We point out typical characteristics of Dutch school mathematics and discuss the aims and challenges in teacher education that result from this. We give examples of different approaches used in Dutch teacher education, which we link to a particular model for designing vocational and professional learning environments. We end the chapter with a reflection on the current situation.
\end{abstract}

\subsection{The Dutch Educational System}

As a start of this chapter we first give an overview of the Dutch educational system. For the sake of clarity, we will focus on the main stream of the system and not go into all exceptions. In other words, we will describe how education is organised for $90 \%$ of the Dutch students. For example, education for students with special needs will

The article is written in the spring of 2016.

\author{
J. Daemen $(\varangle)$ \\ Freudenthal Institute Faculty of Science, Utrecht University, Utrecht, The Netherlands \\ e-mail: j.w.m.j.daemen@uu.nl \\ T. Konings \\ HAN University of Applied Sciences, Nijmegen, The Netherlands \\ e-mail: tonkoningsaijm@gmail.com \\ T. van den Bogaart \\ HU University of Applied Sciences Utrecht, Utrecht, The Netherlands \\ e-mail: theo.vandenbogaart@hu.nl


be left out. After describing the system, we will discuss the different forms of initial teacher education and the statutory framework of required teacher competences that they take as a basis. We end this first section about the Dutch educational system with a discussion of continuous professional development for teachers.

\subsubsection{The School System}

Figure 9.1 shows how the Dutch educational system is organised. By law, education in the Netherlands is compulsory up to the age of eighteen. Primary education lasts eight years from the age of four to twelve. Mother tongue and elementary mathematics are the core subjects. At the end of primary school all students have to take a test; mostly the so-called 'Cito Test' ${ }^{1}$ is used for this. Based on the students' test score and the opinion of the teacher the students are allocated to a particular level of secondary education. Consequently, at the end of primary school the track of students' secondary

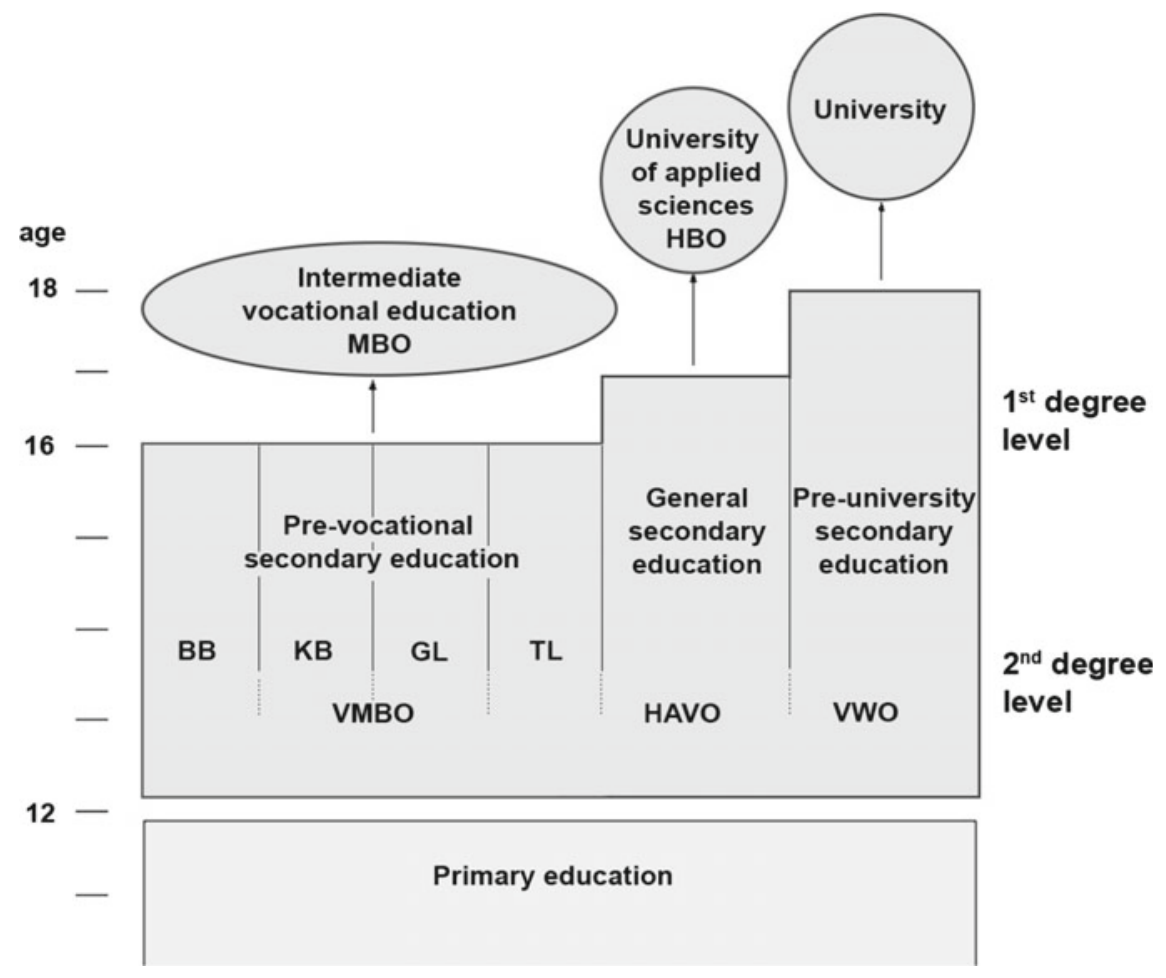

Fig. 9.1 The Dutch school system

\footnotetext{
${ }^{1}$ The Cito End of Primary School Test is developed by Cito, which is the Netherlands national institute for educational measurement.
} 
education is largely determined. The Dutch educational system can therefore be labelled as 'early tracking' - a fact sometimes criticised for its negative consequences on students with a low socio-economic background (OECD, 2007; Onderwijsraad, 2010).

Secondary education is divided in several tracks:

- VMBO: Pre-vocational secondary education, which contains in itself four tracks ranging from practical tot more theoretical, continuing in $\mathrm{MBO}$, intermediate vocational education and training

- HAVO: General secondary education, which qualifies for higher professional education (HBO, also called 'universities of applied sciences') where students can study for primary school teacher and second-degree mathematics teacher, who are qualified for VMBO and the first years of HAVO and VWO

- VWO: Pre-university secondary education, which qualifies for studying at a university where students can study for first-degree mathematics teacher, who are qualified for VMBO and all grades of HAVO and VWO.

After finishing one of these tracks, it is possible to proceed to a higher track. For example, after finishing VMBO, a student can go to HAVO.

Within each track students can choose different directions. All tracks start with the so-called 'basic education', where a broad range of obligatory subjects is offered, including mathematics. For example, when studying at a VMBO school, a student can select one of four profiles: Technology, Care and Welfare, Economics, or Agriculture. In $\mathrm{MBO}$, for which VMBO prepares, mathematics is in general no longer a separate subject, although in recent years government policy has led MBO schools to introduce courses in basic arithmetic.

In HAVO and VWO students have to choose a profile in year four. Here, the profiles are: Culture and Society, Economics and Society, Nature and Health, or Nature and Technology. In VWO mathematics is obligatory in all profiles. In HAVO and VWO, mathematics is distinguished in four kinds of mathematics, ranging from more applied mathematics to more formal and abstract mathematics (see Table 9.1).

At the end of VMBO, HAVO and VWO, there is a national examination in mathematics. The content of the examination is prescribed by the Dutch government. As a result, the curriculum is largely fixed and teachers are largely limited in the topics they teach (Webbink et al., 2009; Snoek, 2011). In contrast with the prescribed

Table 9.1 Mathematics in upper HAVO and VWO

\begin{tabular}{l|l}
\hline Kind of mathematics & Content \\
\hline Mathematics A & Applied analysis in economics and health contexts, statistics \\
\hline Mathematics B & $\begin{array}{l}\text { Formal analysis, analysis applied in technical and scientific contexts, } \\
\text { analytic geometry }\end{array}$ \\
\hline Mathematics C & $\begin{array}{l}\text { (VWO only) Topics aimed at liberal arts, e.g., logic, or symmetry and } \\
\text { perspective in art }\end{array}$ \\
\hline Mathematics D & $\begin{array}{l}\text { (complementary to B) Euclidean geometry, more analysis, choice topics } \\
\text { about applications in technical and scientific contexts }\end{array}$ \\
\hline
\end{tabular}


content, the teachers are free to make their own choice regarding the didactics they use.

\subsubsection{Secondary School Teacher Education}

There are several routes to obtain a qualification to teach mathematics. Although in most countries teacher education involves a study at university level (Deinum, Maandag, Hofman, \& Buitink, 2005), in the Netherlands it is also possible to follow a study at an HBO school. This HBO route to become a mathematics teacher is currently by far the most popular route (source www.stamos.nl) (see Table 9.2).

The main difference between the university route and the HBO route are:

- Admission to a HBO school is less strict than to a university; students from lower secondary education tracks can enrol in a HBO school but not in a university

- The route via university provides a much stronger grounding in formal mathematics

- Universities have a separate curriculum for mathematics and didactics, while HBO schools have an integrated curriculum of mathematics and didactics.

\subsubsection{Secondary School Teacher Education at a HBO School}

There are twelve HBO schools in the Netherlands that provide mathematics teacher education. They offer a four-year bachelor's programme leading to a second-degree qualification. Although the HBO schools were initially meant for students coming directly from secondary school, the current student population is highly heterogeneous: about $65 \%$ (an estimation based on personal communication with staff from several institutions) consist of students between 25 and 65 years old who have decided to make a career move. These older students often already have a job as mathematics teacher. A Dutch law allows them to do this as long as they obtain their qualification within a certain amount of time. The competences acquired by these students before they start their teacher education differ greatly. Some are already qualified for teaching a particular secondary school subject or for teaching primary education, others

Table 9.2 Total number of students in types of secondary school teacher education in 2014

\begin{tabular}{l|l}
\hline $\begin{array}{l}\text { Type of secondary school teacher } \\
\text { education }\end{array}$ & Number of students \\
\hline $\begin{array}{l}\text { HBO teacher education for } \\
\text { second-degree teachers }\end{array}$ & 2,456 \\
\hline $\begin{array}{l}\text { HBO teacher education for first-degree } \\
\text { teachers }\end{array}$ & 322 \\
\hline $\begin{array}{l}\text { University teacher education for } \\
\text { first-degree teachers }\end{array}$ & 40 \\
\hline
\end{tabular}


have a financial or technological background, while there are also students who have not yet done anything related to mathematics or teaching.

The regular (full-time) bachelor's programme at HBO is intended for students who have just completed secondary education. They start with this programme at about the age of seventeen. The older students follow a part-time programme, enabling them to combine their study with a job and family life. The adjective 'part-time' is a bit misleading however. The programme has roughly the same content as the full-time programme and it also lasts four years.

Six of the twelve HBO schools also offer a master's programme for obtaining a first-grade teacher qualification. To be admitted to this programme, two conditions must be fulfilled: one must already have a second-degree qualification and one must work as a teacher in secondary education. This means that the master's programme provides a promotion opportunity for second-degree teachers.

\subsubsection{Secondary School Teacher Education at a University}

Only a small part of the Dutch secondary school mathematics teachers is educated at one of the nine research universities that offer teacher education. Here, three routes are possible.

- Traditionally, teacher education at a university is a post-master's course. Having obtained a master's degree in mathematics or in a related subject, a student has to follow a one-year programme to become a teacher with a first-degree qualification. This route is strongly consecutive: at the start of the post-master's course, a student is already fluent in mathematics.

- Doing the Master's of Science Education and Communication is another option that is offered at five universities. This two-year programme entails, besides mathematical subject knowledge, also theoretical insights and practical skills in both formal and informal educational practices. In this master's course, mathematics is put in a broader societal perspective, relevant to secondary education and to the public at large. The master's course prepares for a first-degree teacher qualification as well as for a career in communication or research and development.

- By following an education minor as part of the Bachelor's of Mathematics, one can obtain a second-degree teacher qualification. The minor takes up to half a year of the bachelor's study, which lasts three years.

The latter two routes have only existed since 2011. The main reason for these additional routes is the shortage of qualified teachers in secondary education.

\subsubsection{Quality Assurance in Teacher Education}

Institutions for teacher education have autonomy in designing their curriculum (Snoek, 2011). Therefore, quality assurance is organised through an accreditation 
system. The accreditation takes place every six years. There is no formal governmental regulation for ensuring the quality of teacher educators, who almost all have at least an appropriate master's degree. Also, there is a voluntary professional register of teacher educators, which is maintained by VELON, the Dutch Association for Teacher Educators.

\subsubsection{Continuous Professional Development}

The types of teacher education described in the previous section can be seen as the starting point for the teacher's professional career. After students have completed the teacher education programme they are fully qualified to teach. Although it is without doubt that a teacher at the start of his or her career as a teacher still has a lot to learn, currently there is no formal policy in the Netherlands, like in other countries (see Deinum et al., 2005), for an induction phase. Nevertheless, life-long learning skills are an important perspective in the curriculum. Therefore, institutions for teacher education tend to focus more and more on 'on the job' education of in-service teachers.

Education in the Netherlands is qualified as good, but compared to other countries the performance of Dutch students in secondary education has started to go a little backwards (SLO, 2015). Since the teacher largely determines the quality of education, the government is taking steps to improve the quality of teachers (Snoek, 2011). The school, as an employer, has the duty to maintain the quality of teachers and give them the opportunity to professionalise continuously. Therefore, schools maintain competence dossiers for every teacher. The Inspection of Education has the task to check the quality of schools and report to the government.

All qualified teachers in the Netherlands have to join the national teacher register. Until August 2017 this was a voluntary registration. Currently, by law, teachers have to participate in professional development activities throughout their working life. They have to spend $40 \mathrm{~h}$ of professional development each year. For mathematics teachers, ten of these hours are labelled as 'involving mathematics'. The Nederlandse Vereniging van Wiskundeleraren ( $\mathrm{NVvW}$; Dutch association of mathematics teachers) and universities provide professional development courses for teachers in order to meet the future requirements for registration in the register of teachers.

Another governmental measure is that teachers can acquire a grant to pursue a bachelor's or master's degree in education, or even a $\mathrm{PhD}$ degree. One reason for this measure is the growing shortage of highly qualified teachers. Another reason is that it gives teachers further career possibilities. 


\subsection{Aims of Teacher Education}

Of course, the aim of initial teacher education is to train people to become a capable mathematics teacher in secondary education in the Netherlands. In this section, we will elaborate on this aim. First, we will discuss the teacher's professional competence from a nationwide, governmental perspective. This involves the question: What makes someone a 'capable' teacher? Then we will highlight the aims with respect to the teacher's knowledge of the didactics of mathematics, mathematical subject knowledge, and research skills.

\subsubsection{Professional Competence a Teacher Must Have}

In the Wet op de Beroepen in het Onderwijs (law on professions in teaching), implemented in 2013, the Dutch government describes the competences a teacher must have. In the resulting statutory framework of competences, the term 'competences' comprises knowledge, skills and attitudes which are specific for the educational domain and sustainable over a longer period of time (Van Merriënboer, Van der Klink, \& Hendriks, 2002). These competences are based on the different roles and situations that teachers can face. The statutory framework of teacher competences is the most important guideline for institutions for teacher education. The framework describes the following competences (Onderwijscoöperatie, 2014):

- Interpersonal competence-the ability to create a learning climate

- Pedagogical competence-aimed at the personal development of students

- Subject knowledge and didactical competence

- Organisational competence

- Competence for collaboration with colleagues

- Competence for collaboration with the environment-e.g., parents, organisations

- Competence for reflection and personal development.

While the previously described statutory framework is meant for teachers in all subjects, the NVvW has presented a professional profile specifically for mathematics teachers (Jonker, Lambriex, Van der Veen, \& Wijers, 2008). The mathematics-related competences are divided in four categories. These are shown in Table 9.3 together with examples of standards.

Based on the statutory framework, the teacher education institutions must indicate what competence level a student must have attained in order to be sufficiently apt to start as a teacher and when a level is reached equal to a bachelor's or master's degree, as prescribed by the international standards for these degrees (see Bologna Working Group on Qualifications Frameworks, 2005). To do so, institutions have to formulate the required 'behavioural indicators' for each competence. Helpful for this are the so-called 'knowledge bases' that, as a result of government policy to raise the quality of teachers (Ministry of Education, 2008), have been developed recently 
Table 9.3 Domain-specific competences for secondary school mathematics teachers (Jonker et al., 2008)

\begin{tabular}{l|l}
\hline Mathematics-related competence & Example of standard \\
\hline Subject knowledge & $\begin{array}{l}\text { A teacher oversees the internal coherence of a } \\
\text { mathematical subject area and links different areas }\end{array}$ \\
\hline Environmental factors & $\begin{array}{l}\text { A teacher knows of the different mathematics related } \\
\text { contents and methodologies in primary education }\end{array}$ \\
\hline Learning processes and didactics & A teacher encourages mathematical activity in the students \\
\hline Assessing, judging and evaluating & $\begin{array}{l}\text { A teacher can analyse students' mistakes and provide them } \\
\text { with adequate feedback }\end{array}$ \\
\hline
\end{tabular}

specifically for domains such as general didactics and pedagogy, educational use of ICT and mathematical subject knowledge at HBO level.

\subsubsection{A Broad Range of Teacher Competences is Required}

Mathematics teachers in secondary education need to be able to teach a broad range of tracks and topics. A second-degree teacher is expected to teach in the lowest track in VMBO up to the third year of VWO. This means that a teacher has to cope with students with quite different levels of understanding. Figure 9.2 exemplifies how the cognitive demands of the tasks in the first year of secondary education can differ in different tracks.

Furthermore, a teacher must also be able to operate in MBO, intermediate vocational education, which places special demands on both subject knowledge (the application of mathematics in the students' future profession and the workplace) and didactics (taking into account the practice-oriented learning style of the students) (see, e.g., Schaap, Baartman, \& De Bruijn, 2012). On top of that, in the last few years it has also become expected of mathematics teachers to teach basic arithmetic in secondary education. This new policy of the Dutch government arose from discontent about secondary school students' arithmetic skills.

The mathematics teacher has to cover a broad range of topics, as the following examples of tasks (Fig. 9.3) may illustrate. Both tasks are from a VWO examination. The first task is from Mathematics C and the second one from Mathematics B (see Table 9.1).

\subsubsection{The Approach to Mathematics Education}

The present approach to mathematics education in the Netherlands is influenced by Realistic Mathematics Education (RME) as formulated by Freudenthal (1991). One of the main principles of RME is that mathematics has to be relevant for students. 


\begin{tabular}{|c|c|c|}
\hline \multicolumn{2}{|c|}{$\begin{array}{l}\text { T-4 Frida rents a bike at 'Budget'. } \\
\text { Budget calculates the price via the formula: } \\
\text { number of days } \times 7.50+5=\text { rental price } \\
\text { The rental price is in Euros. }\end{array}$} & \\
\hline \multicolumn{2}{|c|}{$\begin{array}{l}\text { a. Copy the chain of arrows and place the } \\
\text { numbers } 5 \text { and } 7.50 \text { in the right place. } \\
\text { b. Calculate the rental price if you want to } \\
\text { rent a bike for two days. } \\
\text { c. Make the reverse chain of arrows. } \\
\text { d. Frida has to pay } € 35 \text {, how many days } \\
\text { did she rent a bike? }\end{array}$} & number of days $\stackrel{\times \cdots}{\longrightarrow} \cdots \stackrel{+\cdots}{\longrightarrow}$ rental price \\
\hline \multicolumn{3}{|c|}{$\begin{array}{l}\text { From: Textbook Moderne Wiskunde } 1 B, \text { VMBO-basis, } 2008 \\
\text { (Modern Mathematics } 1 B, V M B O \text {-basic) } \\
\text { (translated from Dutch by the authors) }\end{array}$} \\
\hline \multirow[t]{2}{*}{$\begin{array}{l}\text { T.5 } \\
\text { a } \\
\text { c }\end{array}$} & $\begin{array}{l}\text { Solve the following equations. First write the an } \\
\text { simplify this fraction as much as possible. Then } \\
\text { two decimal places. } \\
\begin{array}{l}4 x=11 \\
6 x=22 \\
16+3 k=35\end{array} \\
\text { This exercise corresponds to section } 11-4 \text {. }\end{array}$ & $\begin{array}{l}\text { er as a fraction and } \\
\text { und off the answer to } \\
\text { d } 14=32-7 p \\
\text { e } 8 t-12=45 \\
\text { f } 1200=22 m+136\end{array}$ \\
\hline & $\begin{array}{l}\text { Ans Karelse is going on a trip to Stonehenge. } \\
\text { England she changes euros to English pounds a } \\
\text { receives } £ 0.69 \text {. For this transaction she has to } \\
\text { Make a formula to calculate the number of pout } \\
\text { she changes } e \text { euros. } \\
\text { How many euros did she change if she received }\end{array}$ & $\begin{array}{l}\text { n she arrives in } \\
\text { bank. For } € 1 \text { she } \\
\text { f } 2.75 \text {. } \\
p \text { she receives when } \\
169.75 \text { ? }\end{array}$ \\
\hline \multicolumn{3}{|c|}{ From: Textbook Modern Mathematics 1B, VWO, 2008 (bilingual track) } \\
\hline
\end{tabular}

Fig. 9.2 Two tasks from the first year of secondary school: one from the lowest track in VMBO (top) and one from VWO (bottom)

According to Freudenthal, mathematics must not be approached as fixed knowledge to be transmitted, but it should be seen as a human activity. Education in mathematics should therefore give students the opportunity to, albeit guided, 're-invent' mathematics by doing it. The focus should be on the process of mathematisation: starting with experiences with contexts or problem situations, from which the student constructs relations between mathematical objects.

In the Netherlands, more than in other countries, school practice seems to be dictated by textbooks (Drijvers, Van Streun, \& Zwaneveld, 2012). The textbooks offer extensive and complete materials for lessons and assessments. Teachers hardly deviate from their textbook (SLO, 2015). The popular textbooks are not unambiguous regarding RME. They incorporate many contexts, but do not use them in mathematisation activities, relying instead on formal definitions and algorithms (Van Stiphout, 
Who is the culprit?

The police has arrested three suspects in the attempted murder of Robert the bus driver: Stolberg, Jones and Fisher. All three deny that they are the murderer. During the interrogation Stolberg claims that Robert is a friend of Jones and that Fisher hated Robert. Jones claims that he does not know Robert at all, and additionally that he was not in town when Robert was stabbed. Fisher claims that he saw both Stolberg and Jones together with Robert in the city, the day Robert was killed and that one of them must have killed Robert.

We assume that only one of the three men is guilty and that the two innocent people speak the truth. To find out who did it, consider the following two statements:

A: Jones speaks the truth

B: Fisher speaks the truth

From the above data it follows that $A \Rightarrow \neg B$ applies.

a. Show that: $A \Rightarrow \neg B$

From $A \Rightarrow \neg B$ follows that either Jones or Fisher is the culprit.

b. Explain who the culprit is.

From: VWO Mathematics C examination in 2013 (translated from Dutch by the authors)

Symmetry

The function $f$ is given by $f(x)=\frac{e^{x}}{\left(e^{x}+1\right)^{x}}$

The graph of $f$ is symmetrical with respect to the $y$-axis. Given the parameter $p$, with $p>0$. In the figure, the area enclosed by the graph of $f$, the $x$-axis and the lines with equation $x=-p$ and $x=p$ is gray.

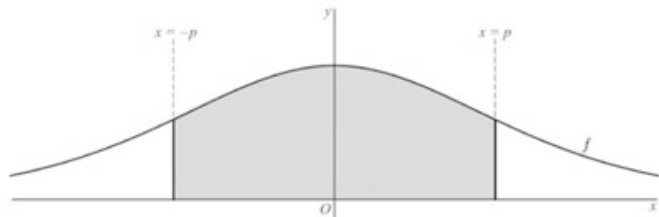

We call the surface of the area $A(p)$.

A primitive $F$ of $f$ is given by $F(x)=-\frac{z}{\left(e^{x}+1\right)}$

a. Prove with the given primitive function that: $A(p)=1-\frac{2}{(e p+1)}$

If $p$ increases indefinitely, $A(p)$ is close to a limit value $L$.

There is a value of $p$ for which $A(p)$ is half of $L$.

b. Calculate the exact' value of $p$.

1: The adjective 'exact' is a Dutch convention, signaling that use of a graphic calculator is not allowed.

From: VWO Mathematics B examination in 2015 (translated from Dutch by the authors)

Fig. 9.3 Tasks in the first-degree area: Mathematics C (top) and Mathematics B (bottom)

2013). Also, policy makers think there is too much weight on procedural knowledge. Therefore, at the moment, there is a strong emphasis on balanced mathematical proficiency (Kilpatrick, Swafford, \& Findell, 2001; cTWO, 2013) in the classroom, incorporating procedural, conceptual and metacognitive knowledge. 
Teachers are expected to employ new technology in their lessons. This includes the use of software as a didactical tool, but also of hardware such as graphic calculators and smartboards and of modern instructional approaches like 'flipping the classroom'.

All the above puts heavy demands on the didactical competence of a mathematics teacher. Being an effective teacher involves much more than just lecturing and helping students with individual problems. It involves asking good questions, engaging students, connecting new and existing knowledge, formative assessments, active learning, use of materials, and the like.

\subsubsection{Mathematical Subject Knowledge for Secondary School Teachers}

\subsubsection{Mathematical Subject Knowledge Taught at HBO Schools}

In the HBO bachelor's programme that qualifies for the second-degree level, about $30 \%$ of the curriculum is devoted to mathematics. The subject knowledge that is required of a second-degree mathematics teacher is described in the nationally agreed Knowledge Base (HBO-raad, 2009). Table 9.4 shows which mathematical domains are included.

In addition to knowledge of these mathematical domains teachers should also have proficiency in skills such as being able to communicate about mathematics, use ICT to explore mathematical situations, being able to model real-life problems. The rationale behind the knowledge base seems to be that a second-degree mathematics teacher needs to be fluent in his subject at a level that surpasses the level of secondary education. This means, in practice, a level that is a little bit more than that of VWO. Also, a second-degree mathematics teacher needs to have knowledge of domains that are related to the application of mathematics in various professions, such as the domain of complex numbers that is necessary for work in electronics.

Table 9.4 Mathematical domains in the Knowledge Base for second-degree mathematics teachers

\begin{tabular}{l|l}
\hline \multicolumn{2}{l}{ Mathematical domain } \\
\hline Calculus & Mainly real valued function in one variable \\
\hline Geometry & $\begin{array}{l}\text { Mainly planar analytic geometry, basic } \\
\text { Euclidean geometry }\end{array}$ \\
\hline Algebra & $\begin{array}{l}\text { Basic algebraic skills and elementary set } \\
\text { theory }\end{array}$ \\
\hline Stochastics & $\begin{array}{l}\text { Probability theory and descriptive and } \\
\text { predictive statistics }\end{array}$ \\
\hline Other domains & $\begin{array}{l}\text { Graph theory, linear optimisation and history } \\
\text { of mathematics }\end{array}$ \\
\hline
\end{tabular}


At the moment, a revision of the Knowledge Base for mathematics is taking place. More than was previously the case, the central question is now what kind of mathematics a mathematics teacher needs to know. Furthermore, a distinction is made between knowledge and skills that must be ready at hand when teaching in prevocational secondary education and the first years of general secondary education, and knowledge a teacher must have heard somewhere in his or her educational career. This discussion is now taking place.

In the HBO master's programme that qualifies for the first-degree level about $60 \%$ of the curriculum is devoted to mathematics. This programme is also based on the Knowledge Base (HBO-raad, 2011), but goes beyond the bachelor's programme, which is extended by, for example, incorporating analysis of several variables and number theory.

\subsubsection{Mathematical Subject Knowledge Taught at Universities}

Teacher education at university implies that students first follow the regular mathematics curriculum and choose the teacher education track when they have already studied mathematics for some time. This means that teachers who graduated from university in general are more proficient in mathematics than their HBO counterparts. In particular, they have a much stronger education in abstract thinking and deductive reasoning.

Students who did not study mathematics at university, but studied a subject in the natural sciences related to mathematics, can also enrol in the teacher education track if they first repair their mathematical deficiencies by following a small subset of courses from the regular mathematics curriculum. Since september 2015, seven special courses can be offered to this category of students: Analysis, Foundations of Mathematics, History of Mathematics, Applied Mathematics, Geometry, Algebra, and Stochastics.

\subsubsection{Research Skills for Secondary School Teachers}

Since about ten years, learning to conduct educational research has become one of the key goals of teacher education. Institutions differ in the research activities that they demand their students do. In several institutions, the focus is on design-based research in which the design can be a sequence of lessons or another instructional design, which the students have to use in practice to see how it works. Sometimes the training school of the students commissions them to do a particular design-based research. Other institutions allow for other types of research. In any case, the research is always aimed at the innovation of a particular practice, not at gaining scientific knowledge. The latter is, as an exception, only included in the two-year teacher education programmes of some universities, which have a research project lasting at least a full semester. 


\subsection{The Curricula for Secondary School Teacher Education}

In this section, we will focus on the part of the curriculum that aims at the third teacher competence of the statutory framework of teacher competences: subject knowledge and didactical competence. We will ignore here the subject knowledge, which is implemented in a more traditional, academic way. In contrast, regarding the didactical competence, the teacher education institutions seem to have adopted a 'practiceoriented approach' of which the key idea is to have the relevant theory closely related to the practical concerns of students who begin to practise teaching (Hammerness, Van Tartwijk, \& Snoek, 2012; Korthagen, Kessels, Koster, Lagerwerf, \& Wubbels, 2001). We will illustrate this approach by giving examples of various learning activities that Dutch institutions for teacher education have incorporated in their curricula. To organise these examples a model (see Fig. 9.4) is used that has been developed for designing vocational and professional learning environments (Zitter, 2010; Zitter, Hoeve, \& De Bruijn, 2016).

The vertical axis is the process dimension, referring to the two kinds of learning processes that the learning activities want to trigger: acquisition versus participation

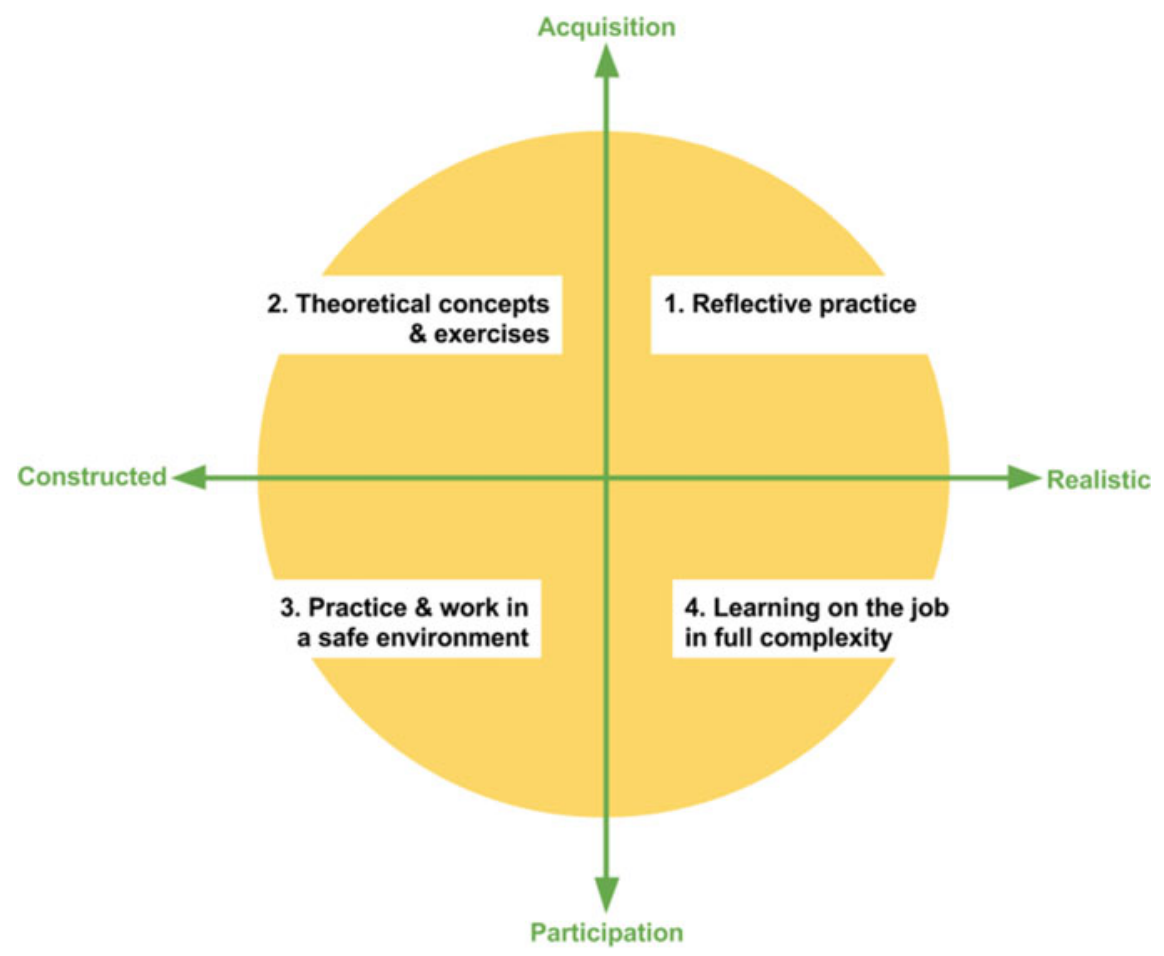

Fig. 9.4 Model to design vocational and professional learning environments (Zitter, 2010; Zitter, Hoeve, \& De Bruijn, 2016) 
(Sfard, 1998). The horizontal axis depicts the condition dimension: from constructed to realistic. Here, there is also a gradual transition in the amount of control by the curriculum and the amount of guidance a teacher educator offers.

\subsubsection{Quadrant 1: Reflective Practice}

Reflection on practice plays an important role in the curriculum. Reflection is the instrument by which experiences are translated into dynamic knowledge (Korthagen et al., 2001). There are several ways, such as showing teacher students video clips or student work, to offer teacher students situations on which they are elicited to reflect. In Example 1 the teacher students have to analyse questions asked of an experienced teacher.

\section{Example 1. Analysis of asked questions}

From: Van Helden, Krabbendam, \& Konings (2011)

(translated from Dutch by the authors)

Assignment: Observe an experienced teacher when he deals with a somewhat large and difficult task. Analyse his behaviour with respect to the questions that are asked related to learning content and problem solving.

In Example 2, the teacher educator does not only have an important role in guiding the reflection, but also in linking mistakes to the underlying didactical theory.

\section{Example 2. From mistakes to didactical theory behind mistakes}

From: Utrecht University's teacher education

(translated from Dutch by the authors)

Assignment: In a group meeting of student teachers, the teacher educator asks about mathematical mistakes the student teachers have observed in their students. The teacher educator collects the mistakes on the blackboard, and in a discussion tries to structure the different cases that are brought in. Together, a case is selected and treated in more detail, for example, a mistake such as

$$
2 \frac{1}{2}-\frac{1}{2}=2, \text { therefore } 2 a-a=2
$$

Students discuss the source of this mistake and possible interventions to remedy it. The teacher educator links this to theory, such as the didactics of the use of variables and operations. Then, a new cycle starts. 


\subsubsection{Quadrant 2: Theoretical Concepts and Exercises}

Having teacher students develop a theoretical framework is an important aspect of teacher education. However, if this happens in isolation, students find it difficult to make a transfer to practice. Therefore, finding applications and linking theory to practice are important. To support theory development by teacher students and link this to practice, it is very helpful that currently several textbooks are available that provide the theoretical basis for the courses in didactics of mathematics. Table 9.5 gives an overview of these textbooks and their content.

In the following two slightly paraphrased examples are given from these textbooks used in teacher education. Example 3 illustrates how in Faes et al. (2011), a textbook meant for teacher education at the second-degree level, the teacher students become acquainted with the different levels on which tasks can be presented to students.

Table 9.5 Textbooks for mathematics teacher education

\begin{tabular}{l|l}
\hline Second-degree level & First-degree level \\
\hline $\begin{array}{l}\text { Serie Wiskunde voor Leerlingen van 12-16, } \\
\text { voor de Lerarenopleiding }\end{array}$ & Handboek Wiskundedidactiek (Handbook \\
(Series Mathematics for Students 12-16, for & Didactics of Mathematics) (Drijvers et al., \\
Teacher Education) & - Learning and teaching mathematics \\
(see Dutch version at http://www.fisme. & - Variables and equations \\
science.uu.nl/wiki/index.php/ & - Functions \\
Samenwerkingsgroep_Lerarenopleiding_ & - The derivative \\
Wiskunde_2e_graads) & - Geometry \\
- Elementary arithmetic & - Probability \\
- Geometry & - Statistics \\
- Algebra & - Modelling \\
& - Technology in mathematics education \\
& - Assessing mathematics \\
\hline $\begin{array}{l}\text { Serie Leren effectief lesgeven, voor de } \\
\text { lerarenopleiding wiskunde (Series Learning } \\
\text { to teach effectively, for teacher education) } \\
\text { (see http://www.fisme.science.uu.nl/wiki/ } \\
\text { index.php/Samenwerkingsgroep_- } \\
\text { Lerarenopleiding_Wiskunde_2e_graads) } \\
\text { - Preparing and developing mathematics } \\
\text { education } \\
\text { - Learning of mathematics } \\
\text { - Problem solving and mathematics } \\
\text { Assessing mathematics }\end{array}$ \\
\hline
\end{tabular}


Through the assignment to analyse a secondary school textbook the teacher students can build experience with recognising this well-known theoretical three-phase model.

\section{Example 3. From concrete to abstract}

From: Faes et al. (2011) (translated from Dutch by the authors)

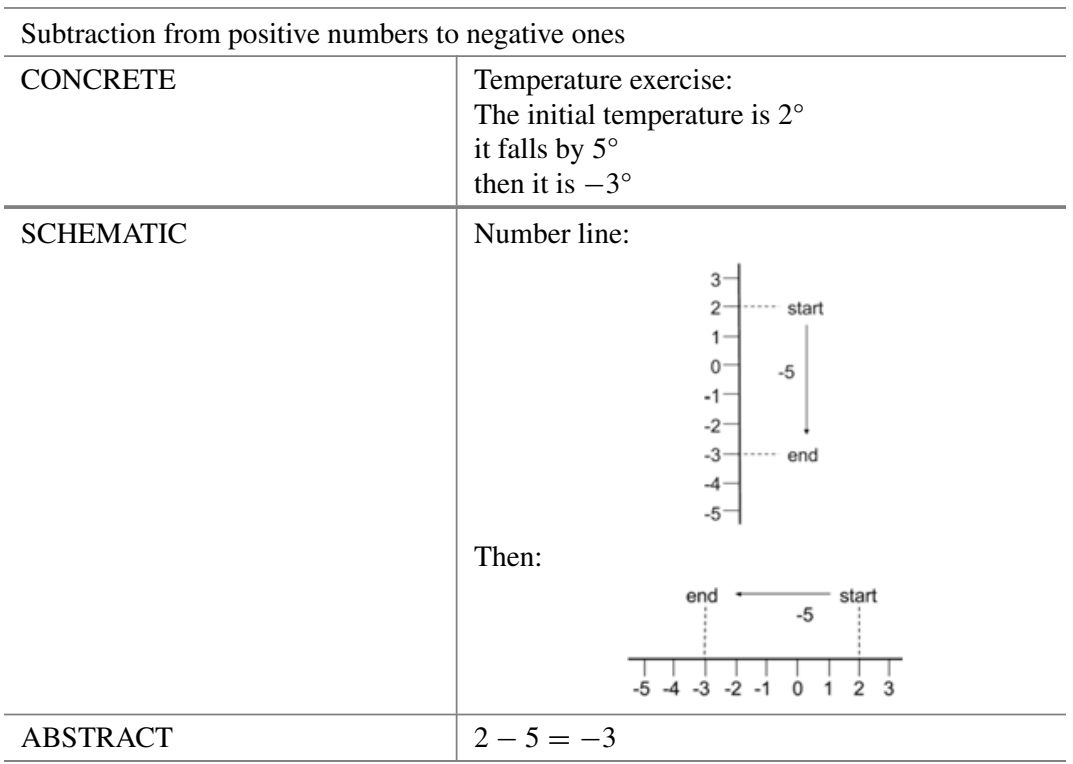

The phases 'concrete-schematic-abstract' are sometimes called the 'context-modelformal' phases.

- Context phase: Students need to familiarise themselves with a context. What is the framework? What does the action look like? Often, you must do this several times.

- Schematic/model phase: In this phase the context is gradually released [...]

Assignment: Check in a secondary school textbook on the pages devoted to addition and subtraction of negative numbers what you notice concerning the transition from concrete to abstract.

Example 4 is taken from Drijvers et al. (2012), the handbook that is used in teacher education for the first-degree level. Here, again the teacher students become acquainted with theoretical didactical knowledge. This time they learn about the concept of function, in particular about how secondary school students can express their understanding of this concept and how this informal understanding by the students can be understood by the teacher at a more abstract level in which several hierarchical categories of understanding can be distinguished. 


\section{Example 4. Concept definitions and images}

From: Drijvers et al. (2012)

(translated from Dutch by the authors)

Previously it has been described that concept images of the concept of a function can vary greatly between students. These differences became apparent when Vinner and Dreyfus asked students what they thought a function was. The answers they obtained fell in six categories:

a. The formal definition from the book: each $x$ in the set $A$ is associated to exactly one element from the set $B$;

b. A dependence relation: $y$ depends on $x$;

c. A rule with a certain amount of regularity;

[...]

When we look at these images a little bit closer, we can make the following hierarchical distinction:

1. The function as an input-output process: this matches the image of a machine. The function $f$ with $f(x)=2 x+3$ for example, is considered as a local computational process: "take twice the input $x$ and add 3 , which gives the output $y$."

2. The function as covariance: $[\ldots]$

3. The function as object: [...]

\subsubsection{Quadrant 3: Practice and Work in a Safe Environment}

A teacher is required to perform many tasks in a complex, hectic environment, where it is not always feasible to reflect, to discuss mistakes and to receive feedback on your teaching. For this reason, the teaching of teacher students is practised in a more controlled, simulated context where there is ample opportunity for analysis and where, moreover, the more complex task of teaching can be subdivided into subtasks (scaffolding).

Example 5 shows an assignment in which the teacher students have to practise whole-class teaching. The example is taken from Faes et al. (2011), one of the courses of the teacher education for the second-degree level. Although the setting is artificial, it creates an opportunity to assess and discuss the didactical choices teacher students have to make.

\section{Example 5. Introducing new content}

From: Faes et al. (2011) (translated from Dutch by the authors)

Assignment: Deliver a presentation in which you give an introduction to new content for Grade 1. This introduction has to last between 10 and $15 \mathrm{~min}$. Your fellow teacher students will simulate to be your secondary school students. 
To prepare your presentation, we recommend to make all relevant tasks from the book yourself and to analyse aspects of the content that are worthwhile to be discussed.

Also, make a written preparation of your presentation in which you address the following questions:

- What is the goal for the students?

- Which questions are you going to ask them?

- Which instructions will you give?

- What materials do you need?

You will find an example of such a preparation in the appendix [...]

Example 6 shows an assignment taken from the first-degree teacher education programme at Utrecht University. The assignment is on curriculum design. Through this assignment, students can become aware of their own conceptions about how a lesson can or should be built up. Moreover, they can also experience that their peers might have other ideas that may have equal merit. It will turn out that most of the choices teacher students make are implicit and are based on the way they have learned the subject themselves when they were secondary school students. When they now have to design lessons themselves, they will learn that choices have to be made.

\section{Example 6. Curriculum Planning}

From: Utrecht University's teacher education

(translated from Dutch by the authors)

Assignment: In [...] you will find a series of problems and fragments copied from Chap. 4 of the secondary school textbook Modern Mathematics, 2 VWO, [...]. The chapter is on Pythagoras's theorem. Only some parts of the chapter are copied and are placed in random order.

a. Think about how you want to deal with this subject, especially in which order. Replace the parts in the order that you prefer. You can leave problems or information which you do not find relevant aside. If this is easier you can cut out the fragments and put them in order.

If it is important you can add missing information in keywords. Note it does not have to cover the complete subject. The idea is to think through the order of teaching.

b. Discuss in pairs where large differences in your order occur. Compare the arguments on which you have based this order. Also discuss the problems you do not use. Write down the arguments.

c. Compare your sequence with the sequence from the original book.

d. If you have time, check out [...]. Discuss what current educational practice requires from students and teachers with regard to the actual curriculum in mathematics education.

e. Plenary exchange: differences on the basis of the arguments. 


\subsubsection{Quadrant 4: Learning on the Job}

Workplace learning, or immersion in the workplace curriculum (Billet, 2006), is a major component in teacher education curricula. In the bachelor's programme, this amounts to approximately $25 \%$ of the programme, culminating in a trajectory where a teacher student has sole responsibility for several classes (see Example 7). In the university master's course (see Example 8), as much as 50\% of the programme takes place in secondary school (Snoek, 2011). Workplace learning is not only arranged through the classic way of an internship. Teacher education institutions seek close cooperation and partnerships with secondary education schools, resulting in a tendency towards 'training-for, training-with-and-in, and training-by' the school for secondary education (Deinum et al., 2005). This has benefit for both. From the perspective of teacher education, a motivating learning environment is created where teacher students can integrate theory and practice and where there is opportunity to become part of the professional community (Schaap et al., 2012). From the school's perspective, having the opportunity for professional development for their personnel and having the occasion to work on innovation and research through this collaboration with a teacher education institution, can serve as an incentive (Snoek, 2011).

\section{Example 7. An internship at the end of the bachelor's programme}

From: Instituut Archimedes (2014) (translated from Dutch by the authors)

Assignment: For a year, deliver, on your own, 6 to 8 lessons weekly. [...] As well as delivering lessons, also perform the following tasks:

- Prepare and grade assessments

- Participate in staff meetings

- Attend report meetings

- Have contact with parents

[Depending on the context,] perform several other activities such as:

- Have contact with support staff

- Design educational products [...]

\section{Example 8. Scaffolding}

From: Utrecht University's teacher education

(translated from Dutch by the authors)

Assignment: Make a video recording of yourself in which you give support to one or more secondary school students. [...] Then, select two video fragments that show interaction. Chose one fragment with interaction where you are satisfied about the way you are giving help to your students and one where you are less satisfied about the help you are giving. 
Regarding the next questions, try to interpret as little as possible and try to reason as much as possible based on what you see. Name as many concepts as possible.

(a) In which respect is scaffolding used in the video fragments? What elements of scaffolding are included? What observations make you say this?

(b) Which elements of scaffolding do you miss? What observations make you say this?

(c) Watch each video fragment according to two principles, namely the 'contingent shift principle' and the 'principle of adaptivity in term of cognitive complexity'; does this lead to the same results?

\subsubsection{Merging All Activities: Exhibiting and Assessing Competence}

The plethora of learning activities in the different quadrants could lead to fragmented learning. Moreover, this could be amplified by the fact that these activities are divided over different courses in the curriculum, which are not all specific for mathematics and are taught by different teacher educators. To prevent this, so-called 'professionrelated tasks', consisting of large, central and targeted assignments, play an important role. This approach is called a 'whole-task' model (Van Merriënboer \& Kester, 2008). Such a task could be, for example, designing a lesson or a test, or designing a lesson series that one has to carry out. Examples 9 and 10 give an impression of such tasks.

Almost all teacher education institutions have as part of their curriculum an extensive assessment in which a teacher student must present a portfolio that gives insights into his or her competences. An interview with a teacher educator and a senior teacher at the training school is often part of this assessment.

Almost always, a teacher educator attends a lesson by a teacher student as part of the teacher education curriculum. This visit sometimes has the form of a summative assessment, although it is frequently used to give constructive feedback and to plan the further developmental needs of the teacher student.

\section{Example 9. Designing a lesson series}

From: Van den Bogaart \& Konings (2015) (translated from Dutch by the authors)

[This text] addresses the preparation of several lessons when treating a chapter in a secondary school textbook, but also in case one has a theme for which one wants to produce materials on one's own.

In a lesson series, there are a great many points of attention:

- How can I analyse the learning content and the textbook? What do my students need to be able to do and know? How can I assess this?

- Which didactical interventions enable me to support the learning of my students? [...] 
[During the chapter, a student teacher designs and carries out a series of lessons. Here is part of the rubric used to grade the teacher student:]

\begin{tabular}{|c|c|c|c|c|}
\hline & Starting & Developing & Competent & Exemplary \\
\hline Content choice & $\begin{array}{l}\text { Choosing a } \\
\text { chapter based } \\
\text { on the } \\
\text { schedule of the } \\
\text { schoo }\end{array}$ & $\begin{array}{l}\text {...and takes } \\
\text { his/her own } \\
\text { didactical } \\
\text { interest into } \\
\text { account }\end{array}$ & $\begin{array}{l}\text {...and takes } \\
\text { the wishes of } \\
\text { the teacher } \\
\text { team of the } \\
\text { school with } \\
\text { respect to } \\
\text { special } \\
\text { innovations } \\
\text { into account }\end{array}$ & $\begin{array}{l}\text {...and takes } \\
\text { the further } \\
\text { development } \\
\text { of his/her } \\
\text { competences } \\
\text { into account }\end{array}$ \\
\hline Learning goals & $\begin{array}{l}\text { "Knowing } \\
\text { that...": } \\
\text { Describes the } \\
\text { goals in detail } \\
\text { and links this } \\
\text { to } \\
\text { representative } \\
\text { tasks }\end{array}$ & $\begin{array}{l}\text { "Knowing } \\
\text { why...": } \\
\text {...and how the } \\
\text { content can } \\
\text { become } \\
\text { meaningful for } \\
\text { the students } \\
{[\ldots]}\end{array}$ & $\begin{array}{l}\text { "Knowing } \\
\text { how...": } \\
\text {...also } \\
\text { long-term } \\
\text { goals are taken } \\
\text { into account } \\
\text { like problem } \\
\text { solving, } \\
\text { reasoning } \\
\text { abilities, }[\ldots]\end{array}$ & $\begin{array}{l}\text { "Knowing } \\
\text { about } \\
\text { knowing...": } \\
\text {...and study } \\
\text { skills are taken } \\
\text { into account }\end{array}$ \\
\hline
\end{tabular}

\section{Example 10. 'Master proof'}

From: Utrecht University's teacher education (translated from Dutch by the authors)

Assignment: To make your 'Master proof' you should develop all the materials and the didactical instructions necessary to outline a lesson unit of subsequent lessons for senior levels in secondary school [...]. This means you should think about the aims and objectives (learning goals), the study guide, work sheets, assessment activities or tests, students' surveys, suggestions for improvements and so forth. It also includes collecting and development of appropriate software, presentations, slides, video's, CDROMs and websites. Furthermore, there needs to be a clear distinction between the materials intended for the secondary school students and the texts meant for you and other teachers, that should be in the teacher guidelines. Finally, the justification of specific parts of the lesson unit needs to be made explicit, recognisable and verifiable.

The lesson unit: In agreement with your mentor at your secondary education training school you will make a particular choice regarding class/grade, topic, duration, timing etc., and you will design a lesson unit of at least 4 and at most 10 lesson hours. When you have discussed the design of the lesson unit with your supervisors (at school and at university) and you have made the appropriate adjustments, you will carry out your 
lessons and evaluate the unit. Using the feedback from the evaluation you will most likely need to make a few more changes in the design.

The product: The final product of your 'Master proof', needs to contain the following components: (i) a justification of your approach; (ii) the students' materials; (iii) a summary of the evaluation and the changes made as a consequence; (iv) a reflection on the process of design and performance of the lesson unit; (v) the teacher guidelines to enable you, or a colleague, to carry out the lesson unit another time.

The assessment: The criteria to assess the quality of the 'Master proof' are derived from an 'advertisement text' in which the requirements for a school subject teacher are described. This means that from your product it should become apparent that:

- You are able to articulate a vision on your school subject and its place in society; [...]

- You show understanding of the construction of the subject curriculum including the performance objectives and assessment goals; [...]

- You understand how students acquire knowledge and understanding of your subject area; $[\ldots]$

- You can plan, give and evaluate lessons (in authentic activities) and you are able to translate your vision, insights and knowledge into effective and entertaining lessons: [...]

- You dared to experiment; $[\ldots]$

\subsection{Reflections on the Current Situation}

In this section, we look at the current state of affairs in secondary school teacher education in the Netherlands and discuss some important merits, challenges and points for improvement. We will follow the ordering used in structuring this chapter. First, we reflect on the educational system, then we focus on the aims of teacher education, and finally we conclude with a reflection on the curricula for secondary school teacher education.

\subsubsection{Reflection on the Dutch Educational System}

In an analysis of mathematics education in the Netherlands, Van Streun (2001) recognises as the most important development during the last century that nowadays almost $100 \%$ of students at age 16 have had mathematics education, while previously this was the prerogative of a small elite. We see two additional merits. First, the quality of mathematics education is high. International comparison in PISA (OECD, 2014) shows that Dutch students do well, especially when compared to other European countries. Second, the content of the mathematics curriculum is tailored to the needs of different student populations. There are many levels, several profiles and several 
kinds of mathematics with their own specific subjects. This diversity in mathematics education that is offered is more apparent than in neighbouring countries (Kaper, 2013). This broad range makes the teacher's job both varied and challenging. Also, it gives ample opportunities for making connections with other school subjects.

Besides these merits, we see several concerns. First, the aforementioned Pisarankings show a score that gradually declines in time. This might indicate a slow but steady decreasing level in relation to other countries. Second, although generally the amount of mathematics lessons is comparable to that of neighbouring countries, this is not the case for students at the highest levels of secondary education that prepare for further study in engineering or the natural sciences-in this respect, the Netherlands is far behind (Kaper, 2013) and this situation has worsened in the last eight years.

Another point that is an issue of concern is that in the Netherlands, there is a shortage of mathematics teachers. The expectation is that this shortage will increase (Fontein, Adriaens, Den Uijl, \& De Vos, 2015). In 2015, 2.2\% of the full-time positions for mathematics teachers could not be filled and this will grow to $5.1 \%$ in ten years. Moreover, a significant part of the jobs is filled by teachers who do not have the required qualification (18.5\% of the lessons in 2013, according to Fontein, De Vos, \& Vloet, 2015).

In the light of this shortage, Dutch mathematics teacher education has two quantity-related problems (Amerom \& Drijvers, 2013). First, the efficiency of teacher education is low and decreasing. Although it is difficult to get precise measures, roughly one third of the teacher students have not completed their study one year after the nominal duration of teacher education. Second, a significant part of those who graduated at a teacher education institution do not become teachers-for example, this is the case for $34 \%$ of second-degree teachers who graduated between 1996 and 2005. Additionally, there are concerns about the very small number of teachers graduating at universities (Commissie Deltaplan Wiskunde.NL, 2015).

A further issue to be worried about is that Dutch teachers have little time for professional development, lesson planning and evaluation, which in part explains the great dependency on textbooks. This is especially a problem for starting teachers, who are often overloaded with work. This can lead to their quitting their job as a teacher.

A striking characteristic of the Dutch system for secondary school teacher education is that there are many routes by which one can acquire a teacher qualification, that there are many teacher education institutions and that these institutions are quite autonomous. This leads to a diverse population of teachers, which is enriching. However, the many routes are not enough. Schools for secondary education demand still more flexibility. On the one hand this is a major point of concern at the moment, but on the other hand there are limits to the flexibility that can be realised due to quality assurance and the small scale of Dutch teacher education (Dekker, 2016). In view of the foregoing, one can raise the question whether the large number of routes and institutions does not lead to too much fragmentation. Especially in teacher education at universities where student population is very low, this is a major problem. Therefore, there is cooperation between institutions. 
Continuous professional development of teachers is an important aspect of current educational policy. At the moment, too many teachers regard receiving their degree as the end point of their development. The professional register of teachers aims to change this, but we fear that it will take some time before this change in culture is realised. Another important aspect is the high dropout rate of beginning teachers. An extension of the duration of teacher education could remedy this. In addition, it would also be helpful for keeping more teachers in their job if teachers had more career possibilities. Currently, Dutch teachers can make progress through getting a higher salary based on length of service as well as by being promoted to higher-ranked positions at their school or at another school. However, compared to other jobs the career perspective for teachers is still small. Also, the teaching profession has a lower status than many other professions (Sikkes, 2015). All these circumstances damage the attractiveness of a teaching job.

Regarding the quality of teacher education, recent accreditations of institutions for teacher education show that mathematics teacher educators as a rule are highly qualified and ambitious. Nevertheless, certain types of professional development for teacher educators could be stimulated more, such as developing knowledge about what it means to combine teacher education with having a teaching job in secondary education. Furthermore, for secondary school teachers who are responsible for the part of the teacher education that takes place in practice in secondary school, more schooling is necessary, especially in the didactics of mathematics.

A particular concern is also the payment of teacher educators: their starting salaries as a rule are lower than those of experienced teachers in secondary educations, which makes it difficult to convince 'the best teachers' to work in teacher education.

Finally, the state of affairs concerning research in the didactics of mathematics is worrisome (Verhoef, Drijvers, Bakker, \& Konings, 2014). The same holds for research on the education of starting mathematics teachers. Although the research output is respectable, there is little budget for further research, although the need of teacher education institutions for validated insights is growing. A positive development is the creation of budgets for teachers to do a PhD study.

\subsubsection{Reflection on the Aims of Dutch Secondary School Mathematics Teacher Education}

Dutch teacher education can be characterised as rather focused on the teaching profession: the learning of teacher students takes place in close contact with practice. There is a rich tradition in cooperation between teacher education institutions and schools for secondary education. However, this cooperation is often on education in general and does not always has a strong link to mathematics. Although competence in the didactics of mathematics is highly valued, it is often subordinated to general educational competences. Recent research (Inspectie van het Onderwijs, 2015), focussing on the second-degree level, pinpoints several strong points in the quality of 
teacher education: reaching a high level of subject knowledge and basic pedagogical and didactical skills in teacher students and realising a high level of competence in teaching and assessment. Nevertheless, there is also room for improvement in focus on curriculum planning, designing assignments, applying differentiation and making links to practice.

As remarked earlier, mathematics teachers in secondary school are strongly guided by their textbooks. The limited time available to teachers for preparation and professional development leads to a conservative way of teaching, which may result in a discrepancy between the aims of teacher education and school practice in secondary education. Thus, there can be a gap between the demands of schools in secondary education and the aims of the teacher education institutions. Governmental policy therefore emphasises having more interchange between secondary education schools and teacher education institutions (Dekker, 2016).

For five years, the mathematical subject knowledge for secondary school teacher education at HBO schools has been captured in the Knowledge Base. This has led to a levelling of the mathematical goals, yet often resulting into a rise of these goals. However, there is discontent among teacher educators with the large amount of detail in the Knowledge Base and putting too much focus on reproductive skills.

Since the requirements on subject knowledge needed to start with teacher education are more and more relaxed, teacher students at universities are often overqualified in this respect. Therefore, there is an ongoing discussion within universities on the balance between academic and practical training necessary to become a teacher. Three years ago, students in secondary school teacher education qualified the academic focus as insufficient (VSNU, 2013). However, at the moment one tends to put more emphasis on good practice preparation, yet, after all, these students have completed an academic study.

Currently, in secondary school teacher education there is a growing emphasis on educational research. Yet it is not evident how to deal with research in teacher education. This especially applies to teacher education at university, where most students have already done extensive research activities outside education, but where there is little opportunity to really let students experience research in an educational context.

A final point of reflection in this section is about the vision on mathematics education. Although, to a large degree, there is a shared vision on mathematics education among secondary school teacher educators, in a broader societal perspective this is not the case. As a result, this is leading to a debate on the main function of mathematics education, namely teaching formal skills versus skills for functional use of mathematics, and this debate impedes curriculum development (SLO, 2015). 


\subsubsection{Reflection on the Curricula for Secondary School Teacher Education}

In the curricula for secondary school teacher education one can distinguish several types of programme components such as theoretical courses aimed at mathematics, the didactics of mathematics, or general educational competences, and more practiceoriented activities like internships and research projects. Parts of these activities take place at the teacher education institutions and other parts in schools for secondary education. Such a curriculum can easily lead to fragmentation. This danger is also mentioned in accreditation reports on the teacher education institutions. Similarly, there is also the danger of having no coherence in the curriculum because activities are divided over different courses in the curriculum, taught by different teacher educators. The profession-related tasks based on the whole-task model we discussed earlier, could be used to obtain coherence between the theoretical courses and practiceoriented activities. This approach should get more emphasis in the secondary school teacher education curricula.

A further aspect where coherence falls short concerns research skills. Achieving a research attitude in future teachers is regarded as a major goal of teacher education. However, doing research often has an isolated place in the curriculum. Linking research to the profession-related tasks enhances the coherence, as this linking is happening more and more.

Another complain that is sometimes heard from secondary school teacher educators is that teacher students have a lack in applying didactical knowledge when teaching their students. A problem is that experts in the didactics of mathematics do not always go to the training school and observe the teacher students' teaching systematically. Coaching in the training school is often limited to giving practical directions. In a one-year teaching education programme at a university, linking theory and practice is difficult to realise. We see room for improvement here with respect to the following points: (1) the role played by the didactical expert in coaching and assessing teacher students' learning in the training school, (2) the establishment of communities of training school coaches and didactical experts, (3) professional courses for training school coaches and (4) an alumni policy to make the realised level of the teacher students more transparent.

\section{References}

Amerom, B., \& Drijvers, P. (2013). De lerarenopleiding wiskunde in Nederland: Instroom, doorstroom en uitstroom [Dutch mathematics teacher education: Inflow, flow, outflow]. Tijdschrift voor Lerarenopleiders, 34(3), 17-26.

Billet, S. (2006). Constituting the workplace curriculum. Journal of Curriculum Studies, 37(3), $31-48$. 
Bologna Working Group on Qualifications Frameworks. (2005). A framework for qualifications of the European higher education area. Copenhagen, Denmakr: Danish Ministry of Science, Technology and Innovation.

Commissie Deltaplan Wiskunde.NL. (2015). Een Deltaplan voor de Nederlandse wiskunde [A Delta plan for mathematics in the Netherlands]. Den Haag/Amsterdam: Nederlandse Organisatie voor Wetenschappelijk Onderzoek/Platform Wiskunde Nederland.

cTWO. (2013). Denken \& doen. Wiskunde op HAVO en VWO per 2015 [Thinking \& doing. mathematics in HAVO and VWO as of 2015]. Utrecht, the Netherlands: cTWO.

Deinum, J., Maandag, D., Hofman, W., \& Buitink, J. (2005). Aspecten van opleiden in de school. Een vergelijkend internationaal overzicht [Aspects of training in school. An international comparison]. Den Haag, the Netherlands: Onderwijsraad.

Dekker, S. (2016). Plan van aanpak tegengaan onbevoegd lesgeven vo. Kamerbrief [Plan of action for discouraging uncertified teaching in secondary education]. Den Haag, the Netherlands: OCW.

Drijvers, P., Van Streun, A., \& Zwaneveld, B. (Eds.). (2012). Handboek wiskundedidactiek [Handbook didactics of mathematics]. Utrecht, The Netherlands: Epsilon.

Faes, T., Goris, T., Konings, T., Krabbendam, H., Monquil, A., \& Staal, H. (2011). Het leren van wiskunde [The learning of mathematics]. Utrecht, The Netherlands: APS.

Freudenthal, H. (1991). Revisiting mathematics education. China lectures. Dordrecht: Kluwer.

Fontein, P., Adriaens, H., Den Uijl, M., \& De Vos, K. (2015). De toekomstige arbeidsmarkt voor onderwijspersoneel PO, VO en MBO 2015-2025. Update oktober 2015 [The future labour market for educational personnel in primary, secondary and lower vocational education 2015-2025. Update October 2015]. Tilburg, the Netherlands: CentERdata.

Fontein, P., De Vos, K., \& Vloet, A. (2015). IPTO: vakken en bevoegdheden. Peildatum 1 oktober 2013 [IPTO: Courses and qualifications. Survey date, October 1, 2013]. Tilburg, The Netherlands: CentERdata.

Hammerness, K., Van Tartwijk, J., \& Snoek, M. (2012). Teacher preparation in the Netherlands: Shared visions and common features. In L. Darling-Hammond, \& A. Liebermann (Eds.), Teacher education around the world. Changing policies and practices. Milton Park/London, UK: Routledge.

HBO-raad. (2009). Kennisbasis, biologie, natuurkunde, scheikunde, techniek, wiskunde [Knowledge base, biology, physics, chemistry, technics, mathematics]. Den Haag, the Netherlands: HBO-raad.

HBO-raad. (2011). Vakinhoudelijke en vakdidactische kennisbasis Hbo-masteropleiding leraar voorbereidend hoger onderwijs [Knowledge base on subject knowledge and subject didactics for HBO-master teacher education for preparatory higher education]. Den Haag, the Netherlands: HBO-raad.

Instituut Archimedes. (2014). Gids studie en werk. Voltijd, jaar 2, 3 en 4. Intern lesmateriaal [Guide for study and work. Full-time, year 2, 3 and 4. Internal lesson material]. Utrecht, The Netherlands: Hogeschool Utrecht.

Inspectie van het Onderwijs. (2015). Beginnende leraren kijken terug. Onderzoek onder afgestudeerden. Deel 2: De tweedegraads lerarenopleiding [Starting teachers look back. Research into graduates. Part 2: The teacher education for the second-degree area]. Utrecht, the Netherlands: Inspectie van het Onderwijs.

Jonker, V., Lambriex, M., Van der Veen, N., \& Wijers, M. (2008). WiVa-wiskundeleraar vakbekwaam. Beroepsregister van wiskundeleraren [WiVa-competent mathematics teacher. Professional register of mathematics teachers]. Nieuwekerk aan den IJssel, the Netherlands: NVvW.

Kaper, L. (2013). Wiskundeonderwijs op het Nederlandse VWO vergeleken met Vlaanderen \& Duitsland [Mathematics education in Dutch VWO compared to Flanders \& Germany] Amsterdam, the Netherlands: Platform Wiskunde Nederland.

Kilpatrick, J., Swafford, J., \& Findell, B. (Eds.). (2001). Adding it up: Helping children learn mathematics. Washington, DC: National Academy Press. 
Korthagen, F., Kessels, J., Koster, B., Lagerwerf, B., \& Wubbels, T. (2001). Linking theory and practice: The pedagogy of realistic teacher education. Mahwah, NJ: Lawrence Erlbaum Associates.

Ministry of Education. (2008). Krachtig meesterschap. Kwaliteitsagenda voor het opleiden van leraren 2008-2011 [A powerful teaching profession. Quality agenda for the education of teachers 2008-2011]. Den Haag, the Netherlands: Ministry of Education, Culture and Science.

OECD. (2007). Thematic review of tertiary education. Paris, France: Organisation for Economic Co-ordination and Development.

OECD. (2014). PISA 2012 Results in focus. Paris, France: Organisation for Economic Co-ordination and Development.

Onderwijscoöperatie. (2014). Voorstel bekwaamheidseisen [Proposal for proficiency requirements. Utrecht, the Netherlands: Onderwijscoöperatie.

Onderwijsraad. (2010). Vroeg of laat. Advies over de vroege selectie in het Nederlandse onderwijs [Early or late. Recommendations about the early selection in Dutch education]. Den Haag: Onderwijsraad. https://www.onderwijsraad.nl/english/publications/2010/early-or-late-tracking/ item1147.

Schaap, H., Baartman, L., \& De Bruijn, E. (2012). Students' learning processes during school-based learning and workplace learning in vocational education: A review. Vocations and Learning, 5(2), 99-117.

Sfard, A. (1998). On two metaphores of learning and the danger of just choosing one. Educational Researcher, 27(2), 4-13.

Sikkes, R. (2015). Status en salaris: Aanzien en aantrekkelijkheid van het leraarsberoep [Status and salary: Prestige and attractiveness of the teaching profession]. Utrecht, The Netherlands: Algemene Onderwijsbond.

SLO. (2015). Curriculumspiegel, deel B: Vakspecifieke trendanalyse [A mirror on the curriculum, part B: Subject-specific trend analysis]. Enschede, The Netherlands: SLO.

Snoek, M. (2011). Teacher education in the Netherlands: Balancing between autonomous institutions and a steering government. In M. C. Zuljan \& J. Vogrinc (Eds.), European dimensions of teacher education-Similarities and differences (pp. 53-82). Ljubljana, Slovenia: University of Ljubljana.

Van den Bogaart, T., \& Konings, T. (2015). Voorbereiden en ontwikkelen van wiskundeonderwijs [Preparing and developing mathematics education]. Utrecht: APS.

Van Helden, H., Krabbendam, H., \& Konings, T. (2011). Probleemoplossen en wiskunde [Problem solving and mathematics]. Utrecht, The Netherlands: APS.

Van Merriënboer, J., \& Kester, L. (2008). Whole-task models in education. In J. Spector, M. Merrill, J. van Merriënboer, \& M. Driscoll (Eds.), Handbook of research on educational communications and technology (3rd ed., pp. 441-456). Mahwah, NJ: Erlbaum/Routledge.

Van Merriënboer, J., Van der Klink, M., \& Hendriks, M. (2002). Competenties: van complicaties tot compromis. Over schuifjes en begrenzers [Competences: from complications to compromises]. Den Haag, the Netherlands: Onderwijsraad.

Van Stiphout, I. (2013). Uit de ivoren toren: Het dubbele didactische spoor in de schoolmethoden [Out of the ivory tower: The twofold didactical track in textbooks]. Nieuwe Wiskrant, 32(3), $32-36$.

Van Streun, A. (2001). Hoe staat ons Nederlands wiskundeonderwijs ervoor? [What is the state of Dutch mathematics education?]. Nieuw Archief voor Wiskunde, 5(2), 42-50.

Verhoef, N., Drijvers, P., Bakker, A., \& Konings, T. (2014). Tussen wal en schip: Wiskundigdidactisch onderwijsonderzoek in Nederland [Between two stools: Mathematical-didactical research in the Netherlands]. Amsterdam, The Netherlands: Platform Wiskunde Nederland.

VSNU. (2013). Actieplan Lerarenagenda Nederlandse Universiteiten [Action plan agenda for teachers Dutch universities]. Den Haag, the Netherlands: VSNU.

Webbink, D., De Wolf, I., Woessman, L., Van Elk, R., Minne, B., \& Van der Steeg, M. (2009). Wat is bekend over de effecten van kenmerken van onderwijsstelsels? [What is known about the effects of characteristics of educational systems?] Den Haag, The Netherlands: Centraal planbureau. 
Zitter, I. (2010). Designing for learning. Studying learning environments in higher professional education from a design perspective. Doctoral dissertation. Utrecht, The Netherlands: Utrecht University \& HU University of Applied Sciences.

Zitter, I., Hoeve, A., \& De Bruijn, E. (2016). A design perspective on the school-work boundary: A hybrid curriculum model. Vocations \& Learning, 9(1), 111-131.

Open Access This chapter is licensed under the terms of the Creative Commons Attribution 4.0 International License (http://creativecommons.org/licenses/by/4.0/), which permits use, sharing, adaptation, distribution and reproduction in any medium or format, as long as you give appropriate credit to the original author(s) and the source, provide a link to the Creative Commons license and indicate if changes were made.

The images or other third party material in this chapter are included in the chapter's Creative Commons license, unless indicated otherwise in a credit line to the material. If material is not included in the chapter's Creative Commons license and your intended use is not permitted by statutory regulation or exceeds the permitted use, you will need to obtain permission directly from the copyright holder.

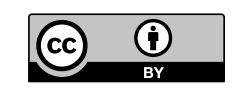

